\title{
Impact of Auditor Competence, Integrity, and Ethics on Audit Quality in Saudi Arabia
}

\author{
Sulaiman A. Alsughayer \\ College of Economics and Administrative Sciences, Imam Mohammad Ibn Saud Islamic University, Riyadh, KSA \\ Email: sasojur@imamu.com.sa
}

How to cite this paper: Alsughayer, S. A. (2021). Impact of Auditor Competence, Integrity, and Ethics on Audit Quality in Saudi Arabia. Open Journal of Accounting, 10, 125-140.

https://doi.org/10.4236/ojacct.2021.104011

Received: August 21, 2021

Accepted: September 12, 2021

Published: September 15, 2021

Copyright $\odot 2021$ by author(s) and Scientific Research Publishing Inc. This work is licensed under the Creative Commons Attribution International License (CC BY 4.0).

http://creativecommons.org/licenses/by/4.0/ (c) (i) Open Access

\begin{abstract}
This research is conducted to investigate the impact of auditor's competency, integrity, and ethics on audit quality from the perceptions of auditors. The data is collected through questionnaires distributed to auditors in auditing firms in Saudi Arabia. The sample used was amounted to 102 auditors. The study surveyed different external auditors to explore their audit process attributes for achieving quality of audit. The findings show that the attributes of competence, integrity, and ethics have significant impact on audit quality. The findings indicate that the most important elements of attributes affecting audit quality are auditors' continuous improvement and training programs, ways of carrying out their duties, and their compliance to code of conduct. This study extends the literature on audit quality and provides useful insights for audit firms and professional bodies for the policies and producers to be adopted and implemented to enhance audit quality.
\end{abstract}

\section{Keywords}

Audit Quality, Auditors, Competency, Integrity, Ethics, Saudi Arabia

\section{Introduction}

Financial information helps investors, analysts, and creditors evaluate a company's financial standing and make decisions accordingly. The financial statement is an important tool to communicate financial information to different stakeholders (Antle \& Nalebuff, 1991). According to FASB, relevance and reliability of the financial statements are very difficult to measure requiring an independent third party's service (an auditor) who attests with reasonable assurance that the statements are relevant and reliable (O’Dwyer, 2011; Enofe et al., 2013b). The auditor's service aims to increase confidence in the financial statements and maintain audit quality. Therefore, audit plays a crucial role as an external cor- 
porate governance mechanism and such audit's governance is ultimately reflected in the quality of the audit per se. The announcement of corporate financial scandals witnessed globally raised interests in corporate governance and turned attention to audit quality. Companies can add credibility to their financial statements and reports by subjecting them to external assurance and verification as a mechanism to improve the quality of financial information (Jensen \& Meckling, 1976; Watts \& Zimmerman, 1986).

The objective of an audit is to obtain reasonable assurance that the financial statements are free from material misstatements and issue an audit report in accordance with the standards (Kesimli, 2019). Hence, the main scope of an audit entails identifying, evaluating, and responding to the risk of fraud or error in financial statements (i.e., material misstatements). Audit quality can be then maintained and improved if material misstatements are detected and reported by an auditor (DeAngelo. 1981). The quality of the audit is impaired if an auditor fails to detect or report material misstatements. Ultimately, the auditor's ability to carry the attestation with reasonable assurance to enhance the credibility of financial statements and consequently provide an elevated level of audit quality, is dependent on specific auditor attributes (DeAngelo, 1982; Johnson et al., 2002; Sulaiman, 2018). These attributes combined shape the audit quality (DeAngelo, 1981).

Literature on audit quality is increasing as time goes by due to the importance attached to it. The focus of audit report has always been centered in the ways audit objectives are realized and audit quality is improved. Accordingly, the objective of this paper is to provide empirical evidence of the impact of an auditor's specific attributes namely competency, integrity, and ethics on audit quality from the perspectives of auditors providing auditing services. This study examines auditors' perception of audit quality and factors influencing audit quality in Saudi Arabia. To the best of the author's knowledge, no study has addressed the combined impact of auditors' competence, integrity, and ethics on audit quality in the context of Saudi Arabia. This research attempts to fill the gap in the auditing literature and explores the implications of sound auditioning and adds to the body of knowledge on the subject matter. The findings of this study will be useful to Saudi Arabia and other Middle Eastern countries as they have similar social, political, and economic contexts hence providing policymakers a mechanism to enhance the profession.

The remaining of the research is organized into four sections. The first section presents the literature review related to the topic of this study and develops the research hypothesizes. The second section presents the research methodology; the data collection and selected sample. Section three discusses the results, followed by the fourth section which outlines the conclusion of the research.

\section{Literature Review and Hypothesis Development}

\subsection{Audit Quality}

Auditing is a mechanism of good corporate governance in companies and can 
improve management and accountability, for both financial and non-financial (Chul-kyu, 2006) and enhance the information quality disclosed to the firms' stakeholders (Beisland \& Hamberg, 2013). Auditing is governed by professional standards and bodies who carry continuous initiatives to develop, change, and introduce auditing rules, regulations, and standards to enhance and promote high-quality audits (Ravenscroft \& Williams, 2005; Casterella et al., 2009; Kilgore et al., 2011). Auditing is performed and completed by independent individuals having acknowledged certifications (Gantz, 2013). Debates concerning auditing profession and regulation seek to enhance the understanding practitioners and involved stakeholders of the factors affecting audit quality in practice (Francis, 2011; Knechel et al., 2012).

Audit quality has no specific definition and as the term is still debated in the literature due to its complexity (Knechel et al., 2013). Van Raak and Thürheimer (2016) state that despite audit quality prominence and the techniques adopted and used to assess it, there is no definition of audit quality and not much information about what could affect it. The most frequently used definition of audit quality in the academic literature is provided by DeAngelo (1981) who defined audit quality as the probability of an auditor detecting and reporting material misstatements in the accounting system of a client. Hence, the main aim of the audit is to provide assurance about the financial statements, the quality of the audit is the possibility that the financial statements will not contain any material misstatement (IFAC, 2009). A higher level of assurances corresponds to a higher quality of audit services.

Prior research has asserted that audit quality relates to the quality of providers of the service in the profession. As such, auditors' competency, independence, integrity, and ethics are important determinants of audit quality (Asmara, 2019; Hardiningsih et al., 2019; Puspitasari et al., 2019; Zahmatkesh \& Rezazadeh, 2017; Darmawan et al., 2017; Schroeder et al., 1986; Carcello \& Neal, 2000; Chen et al., 2001). Accordingly, a high-quality audit can only be achieved by an audit team who possesses knowledge, skills, and experience and adheres to professional ethics, regulations, and audit procedures. Therefore, audit firms face great responsibilities during the implementation of quality control procedures to self-assess their audit teams and processes to uncover and recognize deficiencies that could undermine audit quality (Sanusi et al., 2014). The audit process directly affects the quality of audit services and control of such process is mission of every auditor (Sutton \& Lampe, 1991; Brown et al., 2016).

Audit quality attributes have been a fertile research area for the past two decades. Several studies have examined several measures of the audit quality, some of which have used audit firm size (e.g., Lawrence et al., 2011; Al-Ajmi, 2009; Krishnan \& Schauer, 2000), audit fees, audit tenure (Ghosh \& Mood, 2005), auditor reputation and other studies that have used more accurate measures that rely on statistical indicators and models related to earnings management (Xiao et al., 2020). Some studies have used the audit office's affiliation as Big Four or not (Giroux \& Jones, 2011; Gunn et al., 2019). In this research, the author inves- 
tigates the impact of auditor's competency, integrity, and ethics on audit quality from auditors' perceptions.

\subsection{Hypotheses Development}

The difficulty in measuring audit quality is due to the absence of a complete definition of the main factors that affect audit quality. This research focuses primarily on the professional profile of the auditors and the factors that affected audit quality. Clearly, the quality of audit is not primarily concerning auditing standards but the quality of auditors, their training, ethics including honesty, integrity, fairness, work's experience and how they respond to the regulations of the professional review standards.

Most researchers argue that auditors' skills, personal qualities, staff competencies, and the training given to audit personnel are important factors that determine and affect audit quality. In particular, specific relevant attributes, namely competence, integrity, and ethics, are associated with auditors and directly affect audit quality. The following three following sections will develop hypotheses to investigate the relationship between auditors' personal and professional characteristics and audit quality.

\subsubsection{Impact of Competency on Audit Quality}

Every auditor must meet specific requirements and qualifications to become a professional competent auditor. Competence can be acquired by education, training, exams, professional experience with continuous improvement of the knowledge and skills regarding career changes and developments and appropriate control systems in conformity with the principles and professional standards (Hosseinniakani et al., 2014). The overall knowledge, ability or skills, work attitude, personality, expertise obtained from knowledge and training are all essential attributes that auditors must acquire to gain competence (Bonner \& Lewis, 1990). Auditor's professional competence relates to the auditor's ability to practically and skillfully apply gained knowledge and possessed experience in performing the auditing process objectively, carefully, and accurately (Zahmatkesh \& Rezazadeh, 2017). Practitioners should continuously maintain and develop their professional knowledge to promote their expertise up to the required level so as to provide clients with services based on the latest developments in the field, regulations, techniques, and methods of carrying out the task (Anderson et al., 1998). Knowledgeable and trained auditors will have broader view of auditing and accounting and can spot irregularities in the financial records and statements. Hence, high level of competence can improve the quality of audits. Incompetent will tend to rely on the opinions of others in completing audit tasks, which weakens the audit process and quality (Kertarajasa et al., 2019).

Therefore, the auditor's competence which can be seen from knowledge, skills, and experience, can influence the audit quality. The higher the competence level of an auditor, the more audit quality. Hence, the high level of an auditor will affect the breadth of knowledge he/she has. In addition, more expe- 
riences will enable an auditor to easily detect the falsehood in auditing. Numerous studies have provided evidence that audit competence has a positive impact on audit quality (Pinto et al., 2020; Abdelmoula, 2020; Oktari et al., 2020; Oktari et al., 2020; Kertarajasa et al., 2019; Hajering, 2019; Zahmatkesh \& Rezazadeh, 2017; Pandoyo, 2016; Bouhawia et al., 2015; Furiady \& Kurnia, 2015; Syamsuddin et al., 2014; Usman et al., 2014; Halim et al., 2014; Furiady \& Kurnia, 2015; Zahmatkesh \& Rezazadeh, 2017; Mansouri et al., 2009). Based on the affirmations above, the first research hypothesis is developed as follows:

H1: Competency has a significant positive impact on audit quality.

\subsubsection{Impact of Integrity on Audit Quality}

Integrity is a prerequisite for all those who act in the public interest. Integrity requires auditors to be fair and honest and observe both the ethical standards and the spirit, norm, principles of auditing including independence, objectivity, professional conduct, and protection of public interest (Jelic, 2012; Hikmayah \& Aswar, 2019). Integrity is the essence of public trust and the guideline for auditors when assessing their judgement in relation to relevant ethical standards (Kertarajasa et al., 2019; Suyono, 2012). According to Ningrum and Wedari (2017), the integrity principle dictates that auditors should be honest, courageous, wise, and responsible to build confidence that leads to reliable decisions. If an auditor is characterized as such in carrying out the audit, public trust can be restored and built to enable reliable decision-making (Ningrum \& Wedari, 2017; Wardayati, 2016).

Researchers have shown that auditor integrity is a critical factor in the audit process and positively affects audit quality (Octaviani \& Ekasari, 2021; Prabowo \& Suhartini, 2021; Kamil \& Fathonah, 2020; Kertarajasa et al., 2019; Hikmayah \& Aswar, 2019; Wardayati, 2016; Bouhawia et al., 2015; Furiady \& Kurnia, 2015). The results of the studies asserted that the integrity of an auditor has a significant impact on the quality of audit. Based on the description above, the following hypothesis can be developed:

H2: Integrity has a significant positive impact on audit quality.

\subsubsection{Impact of Ethics on Audit Quality}

Each profession puts great attention on professional ethics of the service catered and the auditing profession is no exception. Auditors who have high norms and ethics are able to produce good audit quality. Campbell (2005) suggested that auditor ethics is the moral principle to guide auditing to generate high-quality audits and ensure the auditor profession can fulfill the obligation to the client and public interest. Auditor professional ethics is a moral principle to guide auditors in performing their audits to achieve and maintain quality audits (Pflugrath et al., 2007). In performing audits, highly competent auditors will always follow audit principles and comply with code of ethics to produce high quality audits. Auditor can promote their audit quality by adopting and applying the ethical requirements embodied in objectivity, prudence, confidentiality, inde- 
pendence, competence, and integrity (Kamil \& Fathonah, 2020; Kertarajasa et al., 2019; Syamsuddin et al., 2014).

The research conducted by Satria (2020); Marsudi (2020); Hikmayah \& Aswar (2019); Arowoshegbe et al. (2017); Oraka \& Okegbe (2015); Enofe et al. (2015); Jelic (2012); and Pflugrath et al. (2007), found that professional ethics had an effect on audit quality and provided evidence that ethics of auditors during the audit process positively contributed to audit quality. Based on these studies and other similar literature, the following hypothesis can be formulated as follows:

H3: Auditor ethics has a significant positive impact on audit quality.

\section{Research Methodology}

This research is based on a questionnaire, a tool for data collection. The researcher uses this method to measure the variables and to collect information about the selected sample. Data is collected through a self-designed English-Arabic questionnaire using Google online form based on a thorough review of the literature. The questionnaire included an introductory cover outlining the research objectives and the author's assurance of confidentiality of information to encourage participants to answer freely and gain high response rate. The questionnaire was structured in four concise sections to collect information from auditors in accounting firms and address the research hypotheses. The first section covers general information. Sections two to four cover the impact of competency, integrity, and ethics on audit quality. The participants were asked to express their opinions to all the questions in the questionnaire which were measured using a five-point Likert scale ( $1=$ strongly disagree to $5=$ strongly agree). The analysis of mean score scale is set as follows: $0.00-1.5=$ very low, $1.51-2.5=$ low, $2.51-3.5=$ moderate, $3.51-4.5=$ high, $4.51-5.00=$ very high. All questions were closed-ended except for some general information.

\section{Population and Sample}

The targeted sample consists of auditors in local and international accounting and auditing firms performing external auditing services in Saudi Arabia. The desired sample was determined and selected using the Cochran's formula and random sampling method. The Cochran formula is:

$$
n_{0}=\frac{Z^{2} p q}{e^{2}}
$$

where:

- $Z$ : value from standard normal distribution table and given the $95 \%$ confidence interval is equal to 1.96 ;

- $p$ : researcher considers ratio of success at 0.50 ;

- $q$ is $1-p$,

- $e$ : the amount of tolerable error in the measurement of variable which is equal to 0.07 in this study. 


$$
\left(1.96^{2} \times 0.5 \times 0.5\right) / 0.07^{2}=196 .
$$

Based on the Cochran formula, the sample comprised a total of (200) randomly selected auditors from local and international auditing firms. Out of the surveys sent online to respondents, a total of (102) were returned and used in the study. The response rate was $48.5 \%$ and is deemed suitable to achieve the objectives. Surveyed participants were mainly highly educated and experienced accountants performing auditing tasks. Some of them are fully or partially certified accountant or in the process of setting for the certification exam as required by their firms after being in service for a couple of years. The data was collected from March to April 2020.

\section{Results and Discussion}

After the text edit has been completed, the paper is ready for the template. Duplicate the template file by using the Save As command, and use the naming convention prescribed by your journal for the name of your paper. In this newly created file, highlight all of the contents and import your prepared text file. You are now ready to style your paper.

\subsection{General Information of Participants}

The distribution of responses is presented according to gender, education level, job position, professional qualifications, accounting firm types, age, number of employees, and years of experience. Table 1 summarizes the characteristics of the respondents.

Table 1. Characteristics of respondents.

\begin{tabular}{|c|c|c|c|c|c|c|c|}
\hline \multirow{4}{*}{ Gender } & Answers & Freq. & Percent & \multirow{4}{*}{$\begin{array}{l}\text { Accounting } \\
\text { Firm Type }\end{array}$} & Answers & Freq. & Percent \\
\hline & Male & 57 & 55.9 & & Local & 82 & 80.4 \\
\hline & Female & 45 & 44.1 & & International & 20 & 19.6 \\
\hline & Total & 102 & 100.0 & & Total & 102 & 100.0 \\
\hline \multirow{5}{*}{ Education } & Bachelor & 58 & 56.9 & \multirow{5}{*}{ Age } & $23-25$ & 25 & 24.5 \\
\hline & High Diploma & 3 & 2.9 & & $26-35$ & 40 & 39.2 \\
\hline & Master & 33 & 32.4 & & $36-45$ & 18 & 17.6 \\
\hline & $\mathrm{PhD}$ & 8 & 7.8 & & More than 46 & 19 & 18.6 \\
\hline & Total & 102 & 100.0 & & Total & 102 & 100.0 \\
\hline \multirow{5}{*}{ Position } & Audit Partner & 36 & 35.3 & \multirow{5}{*}{$\begin{array}{c}\text { No. of } \\
\text { Employee }\end{array}$} & $0-20$ & 4 & 3.9 \\
\hline & Managing Partner & 22 & 21.6 & & $21-40$ & 36 & 35.3 \\
\hline & Senior Auditor & 8 & 7.8 & & $41-60$ & 42 & 41.2 \\
\hline & Junior Auditor & 36 & 35.3 & & More than 61 & 22 & 21.6 \\
\hline & Total & 102 & 100.0 & & Total & 102 & 100.0 \\
\hline \multirow{4}{*}{$\begin{array}{l}\text { Professional } \\
\text { Qualifications }\end{array}$} & Qualified & 33 & 32.4 & \multirow{4}{*}{ Experience } & $0-5$ years & 16 & 15.7 \\
\hline & Not qualified & 50 & 49.0 & & $6-10$ years & 41 & 40.2 \\
\hline & $\begin{array}{l}\text { Partially } \\
\text { Qualified }\end{array}$ & 19 & 18.6 & & $\begin{array}{c}\text { More than } \\
11 \text { years }\end{array}$ & 45 & 44.1 \\
\hline & Total & 102 & 100.0 & & Total & 102 & 100.0 \\
\hline
\end{tabular}


The majority of the responses $(55.9 \%)$ were received from males; however, accounting is still a preferred specialty for females; there is gender equality in the profession. The results show that (56.9\%) of respondents hold a bachelor degree or above with $(40.6 \%)$ holding a postgraduate degree, which reflects the high education level of the participants adding value to the competency of the auditing process. The distribution of responses by position shows that there is an equal percentage $(35.35 \%)$ of partners and junior auditors, which means accounting firms are managed directly by managing partners. The majority (67.6\%) of the respondents hold no auditing qualification, although (18.6\%) have set for specific exams but did not pass all the sections. An overwhelming (80.4\%) of the respondents are working in local accounting firms. The results show that (63.7\%) of those surveyed were less than 35 years old, whereas only (18.6\%) are above 46 of age. The majority of the accounting firms (96.1\%) have more than 21 employees with more than 6-year experience in accounting and auditing (84.3\%). Respondents with work experience of more than 11 years comprised (44.1\%) of the sample playing a major role in the quality of audits.

\subsection{Competency}

This section discusses the results related to the impact of auditors' competence on audit quality. The mean of the six statements as shown in Table 2 is between 4.30 and 3.95, and it is considered very high. This result indicates that most participants recognized the importance and significant positive impact of competence on audit quality. Hence, the vast majority of the respondents agreed that auditor competence based on the knowledge, continuous improvement and training, ability to discover professional experience and certification, educational has a significant impact on audit quality. From the empirical results, it can be concluded that the higher the competence of an auditor, the better the audit

Table 2. Perceptions of the respondent towards competence.

\begin{tabular}{lccc}
\hline \multicolumn{1}{c}{ Statements } & Mean & Std. Dev & Importance \\
\hline $\begin{array}{l}\text { Auditor's knowledge of professional auditing standards, } \\
\text { regulations, and producers leads to significant and } \\
\text { positively affects audit quality. }\end{array}$ & 4.25 & 0.754 & 4 \\
$\begin{array}{l}\text { Auditor's continuous improvement and training } \\
\text { programs enhance his competence and audit quality. }\end{array}$ & 4.30 & 0.742 & 1 \\
$\begin{array}{l}\text { Competency increases the ability to discover material } \\
\text { errors in the financial reports hence enhancing audit } \\
\text { quality. }\end{array}$ & 4.29 & 0.669 & 3 \\
$\begin{array}{l}\text { The professional experience of an auditor leads to } \\
\text { competence and positively affects the quality of the audit. }\end{array}$ & 4.24 & 0.760 & 5 \\
$\begin{array}{l}\text { Auditor's professional certification enhances his } \\
\text { competence and audit quality. }\end{array}$ & & & \\
$\begin{array}{l}\text { The educational qualification of an auditor directly affects } \\
\text { his competence and, consequently, audit quality. }\end{array}$ & 3.95 & 0.776 & 6.885 \\
\hline
\end{tabular}


quality. Competence is fundamental to becoming an auditor. To produce a quality audit report, the auditor must be equipped with proper knowledge and experience to perform the audit tasks. The respondents believe that the most important element affecting audit quality in relation to competence is auditors' continuous improvement and training programs which generally leads to better understanding of auditing regulations and producers. Surprisingly, the evidence of this research shows that educational qualification has the least impact on audit quality in relation to competence.

The results confirm the first hypothesis that competence has a positive impact on audit quality and support several research results (e.g., Pinto et al., 2020; Kertarajasa et al., 2019; Zahmatkesh \& Rezazadeh, 2017; Pandoyo, 2016; Bouhawia et al., 2015; Syamsuddin et al., 2014; Usman et al., 2014; Halim et al., 2014; Mansouri et al., 2009).

\subsection{Integrity}

This section discusses the results of the impact of auditors' integrity on audit quality. The mean of the six statements as shown in Table 3 is between 4.35 and 3.17 and it is considered very high, then the results show that integrity has a positive impact on audit quality. This means that the higher the integrity, the better the audit quality will be. Auditor integrity plays a significant role in audit quality, and auditors should strive to maintain their integrity. The respondents believe that the most critical element affecting audit quality concerning integrity is the way the auditor carries out his audit duties by upholding the principle of honesty, diligence, reasonability, and objectivity.

Table 3. Perceptions of the respondents towards integrity.

\begin{tabular}{lccc}
\hline \multicolumn{1}{c}{ Statements } & Mean & Std. Dev & Importance \\
\hline $\begin{array}{l}\text { The principle of independence of the auditor enhances } \\
\text { the integrity and must be maintained to achieve audit } \\
\text { quality. }\end{array}$ & 4.25 & 0.776 & 4 \\
$\begin{array}{l}\text { Auditors should have open communication on } \\
\text { integrity violations and how they are dealt with to } \\
\text { maintain audit quality. }\end{array}$ & 4.29 & 0.726 & 3 \\
$\begin{array}{l}\text { Auditors shall maintain the integrity by not knowingly } \\
\text { being a party to any illegal activity or engaging in } \\
\text { discreditable acts to the auditing profession or the } \\
\text { company. }\end{array}$ & 3.17 & 1.186 \\
$\begin{array}{l}\text { The auditor's ability to freely report any errors } \\
\text { in the financial reports reflects the auditor's } \\
\text { integrity and audit quality. }\end{array}$ & & \\
$\begin{array}{l}\text { Auditor's honesty, diligence, responsibility, and } \\
\text { objectivity enhance the integrity and must } \\
\text { be maintained to achieve audit quality. }\end{array}$ & 3.60 & 1.119 \\
$\begin{array}{l}\text { Compliance of auditors to audit code of conduct } \\
\text { enhances the integrity and results in audit quality. }\end{array}$ & & \\
\hline
\end{tabular}


The results confirm the second hypothesis that integrity has a positive influence on audit quality are in line with research conducted by Octaviani \& Ekasari (2021); Prabowo \& Suhartini (2021); Kamil \& Fathonah (2020); Kertarajasa et al. (2019); Hikmayah \& Aswar (2019); Wardayati (2016); Bouhawia et al. (2015); and Furiady \& Kurnia (2015).

\subsection{Ethics}

This section discusses the results of the impact of auditors' ethics on audit quality. The mean of the six statements is as shown in Table 4 is between 4.23 and 3.50 , and it is considered very high, then the results show that ethics has a significant positive impact on audit quality. The higher the level of ethics that an auditor has, the better the quality of an audit. The ethics of auditors play a major role in audit quality and should be monitored and controlled through strict policies and procedures to assure adherence to the code of ethics and consequently achieve the desired quality audit. The respondents believe that the most important element affecting audit quality in relation to ethics is the compliance of auditors to code of ethics which will be reflected in the auditor's integrity, objectivity, professional behavior, and many more. Therefore, auditors are required to uphold ethics and maintain professionalism according to auditing standards and regulatory bodies should make much effort in ensuring that ethics are standardized and enforced strictly.

The results confirm the third hypothesis that ethics has a significant positive impact on audit quality and are consistent with research conducted by Satria (2020); Marsudi (2020); Hikmayah \& Aswar (2019); Arowoshegbe et al. (2017); Oraka \& Okegbe (2015); Enofe et al. (2015); Jelic (2012); and Pflugrath et al. (2007).

Table 4. Perceptions of the respondent towards ethics.

\begin{tabular}{lccc}
\hline \multicolumn{1}{c}{ Statements } & Mean & Std. Dev & Importance \\
\hline $\begin{array}{l}\text { Professional ethics should be monitored and controlled } \\
\text { through implemented policies and procedures to } \\
\text { assure adherence to the code of ethics and }\end{array}$ & 4.20 & 0.707 & 2 \\
consequently achieve a quality audit. & & \\
$\begin{array}{l}\text { Auditor's objectivity by avoiding conflict of interest, } \\
\text { bias, or undue influence of others to override professional } \\
\text { or business judgments assures audit quality. }\end{array}$ & 3.50 & 0.966 \\
$\begin{array}{l}\text { Auditor's professional competence and due care indicates } \\
\text { his commitment to the code of ethics and, consequently, } \\
\text { audit quality. }\end{array}$ & 4.19 & 0.796 \\
$\begin{array}{l}\text { Auditor's respect for the confidentiality of information } \\
\text { enhances audit quality. }\end{array}$ & & \\
$\begin{array}{l}\text { Auditor's professionalism by complying with relevant } \\
\text { regulations and avoidance of actions that discredits the } \\
\text { profession enhances audit quality. }\end{array}$ & 4.08 & 0.880 \\
$\begin{array}{l}\text { Auditor's compliance with the code of ethics results in a } \\
\text { quality audit. }\end{array}$ & 4.23 & 0.799 \\
\hline
\end{tabular}


Overall, the results indicate that audit quality is perceived and expected to be high if auditors adhere to the general principles or rules of competence, integrity, and ethics. If an auditor adheres to these principles, that the resulting audit quality will most likely improve. Conversely, if the auditor or any of his auditing team violates these principles and rules the quality of the performed audit is assumed to be low. To restore the public trust and confidence in the profession, auditors should produce their audits with higher quality. For this purpose, auditors needed to maintain their competence, integrity, and ethics so that the resulting audit would be in the favor of the public.

\subsection{Reliability Test}

This research used Cronbach's alpha to measure the reliability of the questionnaire. The consistency of a measure is reliable if the different items in the instrument lead to a similar result (Zikmund et al., 2010). Smith (2019) asserted that $60 \%$ is a reliable and hence an acceptable reliability coefficient level. The results in Table 5 show that Cronbach's Alpha for all the three attributes (competence, integrity, and ethics) is higher than 0.6 , an acceptable value and indicates consistency among statements describing the attribute.

\section{Conclusion}

This research is conducted to determine the impact of auditor's competence, professional integrity, and ethics on audit quality from the perceptions of auditors. The study surveyed auditors to explore their audit process attributes for achieving quality of audit. The findings show that competence, integrity, and ethics have a significant impact on audit quality. The results show that when it comes to audit quality, auditors emphasize continuous improvement and training programs, ways of carrying out their duties, and compliance to code of conduct.

This study extends the literature on audit quality as it improves auditors' understanding of the importance of audit quality and provides useful insights for audit firms and professional bodies for the policies and producers to be adopted and implemented to enhance audit quality. This study contributes to audit quality literature by providing useful insights to audit firms for improving audit quality. Auditing firms should struggle to build and develop the competence of their auditors and auditing teams which directly result in strengthening and

Table 5. Reliability test.

\begin{tabular}{cc}
\hline \multicolumn{2}{c}{ Reliability Statistics } \\
\hline Attributes & Cronbach's Alpha \\
\hline Competence & 0.811 \\
Integrity & 0.606 \\
Ethics & 0.706 \\
\hline
\end{tabular}


enhancing audit quality. Integrity should be exercised and maintained throughout the entire auditing process to achieve the desired quality of the audit. Audit firms should pay more attention to ethics and auditors are expected to strictly comply with the code of ethics to restore the public's trust.

Even though the study's findings provide much evidence regarding auditing quality, it is limited by the sample, and the context since the respondents represent a small sample. The size of the sample was small and covered only central provenance in Saudi Arabia. Further, the study used only three audit attributes as determents of audit quality; hence future research should cover other attributes and variables to gain insightful results. The measure of audit quality is a dichotomy variable; for more precision and reliability, an econometric model should be used in future studies.

\section{Acknowledgements}

I gratefully thank my postgraduate student Mrs. Njoud Alfarraj for her help in the data collection, without her assistance this study would not have been completed.

\section{Conflicts of Interest}

The author declares no conflicts of interest regarding the publication of this paper.

\section{References}

Abdelmoula, L. (2020). Impact of Auditor's Competence, Independence and Reputation on the Joint Audit Quality: The Tunisian Context. Academy of Accounting and Financial Studies Journal, 24, 2-11.

Al-Ajmi, J. (2009). Audit Firm, Corporate Governance, and Audit Quality: Evidence from Bahrain. Advances in Accounting, 25, 64-74. https://doi.org/10.1016/j.adiac.2009.02.005

Anderson, B., Maletta, M., \& Wright, A. (1998). Perceptions of Auditor Responsibility: Views of the Judiciary and the Profession. International Journal of Auditing, 2, 215-232. https://doi.org/10.1111/1099-1123.00041

Antle, R., \& Nalebuff, B. (1991). Conservatism and Auditor-Client Negotiations. Journal of Accounting Research, 29, 31-54. https://doi.org/10.2307/2491002

Arowoshegbe, A., Uniamikogbo, E., \& Atu, G. (2017). Accounting Ethics and Audit Quality in Nigeria. Asian Journal of Economics, Business and Accounting, 4, 1-15. https://doi.org/10.9734/AJEBA/2017/34826

Asmara, R. Y. (2019). Effect of Complexity, Due Professional Care, and Auditor Ethics on Audit Quality. International Journal of Multidisciplinary Research, 5, 18-25.

Beisland, L. A., \& Hamberg, M. (2013). Earnings Sustainability, Economic Conditions and the Value Relevance of Accounting Information. Scandinavian Journal of Management, 29, 314-324. https://doi.org/10.1016/j.scaman.2013.02.001

Bonner, S. E., \& Lewis, B. L. (1990). Determinants of Auditor Expertise. Journal of Accounting Research, 28, 1-20. https://doi.org/10.2307/2491243

Bouhawia, M. S., Irianto, P. G., \& Baridwan, Z. (2015). The Effect of Working Experience, 
Integrity, Competence, and Organizational Commitment on Audit Quality (Survey State Owned Companies in Libya). IOSR Journal of Economics and Finance (IOSR-JEF), 6, 60-67.

Brown, V. L., Gissel, J. L., \& Neely, D. G. (2016). Audit Quality Indicators: Perceptions of Junior-Level Auditors. Managerial Auditing Journal, 31, 949-980.

https://doi.org/10.1108/MAJ-01-2016-1300

Campbell, T. (2005). Introduction: The Ethics of Auditing. The Australian National University E Press.

Carcello, J. V., \& Neal, T. L. (2000). Audit Committee Composition and Auditor Reporting. The Accounting Review, 75, 453-467. https://doi.org/10.2308/accr.2000.75.4.453

Casterella, J. R., Jensen, K. L., \& Knechel, W. R. (2009). Is Self-Regulated Peer Review Effective at Signaling Audit Quality? The Accounting Review, 84, 713-735. https://doi.org/10.2308/accr.2009.84.3.713

Chen, C. J., Shome, A., \& Su, X. (2001). How Is Audit Quality Perceived by Big 5 and Local Auditors in China? A Preliminary Investigation. International Journal of Auditing, 5, 157-175. https://doi.org/10.1111/j.1099-1123.2001.00332.x

Chul-kyu, K. (2006). Market Economy and Corporate Governance Fairness and Transparency for Sustainable Growth. 6th Global Forum on Reinventing Government.

Darmawan, D., Sinambela, E. A., \& Mauliyah, N. I. (2017). The Effect of Competence, Independence, and Workload on Audit Quality. Journal of Academic Research and Sciences, 2, 47-57. https://doi.org/10.30957/jares.v2i2.404

DeAngelo, L. E. (1981). Auditor Size and Audit Quality. Journal of Accounting and Economics, 3, 183-199. https://doi.org/10.1016/0165-4101(81)90002-1

DeAngelo, L. E. (1982). Mandated Successful Efforts and Auditor Choice. Journal of Accounting and Economics, 4, 171-203. https://doi.org/10.1016/0165-4101(82)90008-8

Enofe, D., Ukpebor, I., \& Ogbomo, N. (2015). The Effect of Accounting Ethics in Improving Auditor Professional Skepticism. International Journal of Advanced Academic Research-Social Sciences and Education, 1, 1-16.

Francis, J. R. (2011). A Framework for Understanding and Researching Audit Quality. Auditing: A Journal of Practice \& Theory, 30, 125-152.

https://doi.org/10.2308/ajpt-50006

Furiady, O., \& Kurnia, R. (2015). The Effect of Work Experiences, Competency, Motivation, Accountability and Objectivity towards Audit Quality. 2nd Global Conference on Business and Social Science, Vol. 211, 328-335. https://doi.org/10.1016/j.sbspro.2015.11.042

Gantz, S. D. (2013). The Basics of IT Audit: Purposes, Processes, and Practical Information. Elsevier. https://doi.org/10.1016/B978-0-12-417159-6.00008-0

Ghosh, A., \& Moon, D. (2005). Auditor Tenure and Perceptions of Audit Quality. The Accounting Review, 80, 585-612. https://doi.org/10.2308/accr.2005.80.2.585

Giroux, G., \& Jones, R. (2011). Measuring Audit Quality of Local Governments in England and Wales. Research in Accounting Regulation, 23, 60-66.

https://doi.org/10.1016/j.racreg.2011.03.002

Gunn, J. L., Kawada, B. S., \& Michas, P. N. (2019). Audit Market Concentration, Audit Fees, and Audit Quality: A Cross-Country Analysis of Complex Audit Clients. Journal of Accounting and Public Policy, 38, 1-21. https://doi.org/10.1016/j.jaccpubpol.2019.106693

Hajering, M. S. (2019). Moderating Ethics Auditors Influence of Competence, Accountability on Audit Quality. Jurnal Akuntansi, 23, 468-481. 
https://doi.org/10.24912/ja.v23i3.614

Halim, A., Sutrisno, T., \& Achsin, M. (2014). Effect of Competence and Auditor Independence on Audit Quality with Audit Time Budget and Professional Commitment as a Moderation Variable. International Journal of Business and Management Invention, 3, 64-74.

Hardiningsih, P., Januarti, I., Oktaviani, R. M., Srimindarti, C., \& Udin, U. (2019). Determinants of Audit Quality: An Empirical Insight from Indonesia. International Journal of Scientific and Technology Research, 8, 570-578.

Hikmayah, N., \& Aswar, K. (2019). The Impact of Factors on the Audit Quality in Indonesia: The Moderating Effect of Professional Commitments. International Journal of Academic Research in Accounting, Finance and Management Sciences, 9, 285-293.

https://doi.org/10.6007/IJARAFMS/v9-i4/6916

Hosseinniakani, S. M., Inácio, H., \& Mota, R. (2014). A Review on Audit Quality Factors. International Journal of Academic Research in Accounting, Finance and Management Sciences, 4, 243-254.

International Federation of Accountants (IFAC) (2009). Overall Objectives of the Independent Auditor and the Conduct of an Audit in Accordance with International Standards on Auditing. International Standard on Auditing (ISA) No. 200, IFAC.

Jelic, M. (2012). The Impact of Ethics on Quality Audit Results. International Journal for Quality Research, 6, 333-342

Jensen, M. C., \& Meckling, W. (1976). Theory of the Firm: Managerial Behavior, Agency Costs and Ownership Structure. Journal of Finance Economics, 3, 305-360. https://doi.org/10.1016/0304-405X(76)90026-X

Johnson, V. E., Khurana, I. K., \& Reynolds, J. K. (2002). Audit-Firm Tenure and the Quality of Financial Reports. Contemporary Accounting Research, 19, 637-660. https://doi.org/10.1506/LLTH-JXQV-8CEW-8MXD

Kamil, K., \& Fathonah, N. (2020). The Effect of Independence, Integrity, Professionalism, and Professional Skepticism on the Accuracy of Giving Audit Opinion (The Case of Audit Board of the Republic of Indonesia). Advances in Economics, Business and Management Research, 127, 5-10. https://doi.org/10.2991/aebmr.k.200309.002

Kertarajasa, A. Y., Marwa, T., \& Wahyudi, T. (2019). The Effect of Competence, Experience, Independence, Due Professional Care, and Auditor Integrity on Audit Quality with Auditor Ethics as Moderating Variable. Journal of Accounting, Finance and $\mathrm{Au}-$ diting Studies, 5, 80-99. https://doi.org/10.32602/jafas.2019.4

Kesimli, I. (2019). External Auditing and Quality. Springer. https://doi.org/10.1007/978-981-13-0526-9

Kilgore, A., Radich, R., \& Harrison, G. (2011). The Relative Importance of Audit Quality Attributes. Australian Accounting Review, 21, 253-265. https://doi.org/10.1111/j.1835-2561.2011.00141.x

Knechel, W. R., Krishnan, G., Pevzner, M., Shefchik, L., \& Velury, U. (2013). Audit Quality: Insights from the Academic Literature. Auditing: A Journal of Practice \& Theory, 32, 385-421. https://doi.org/10.2308/ajpt-50350

Knechel, W. R., Sharma, D. S., \& Sharma, V. D. (2012). Non-Audit Services and Knowledge Spillovers: Evidence from New Zealand. Journal of Business Finance \& Accounting, 39, 60-81. https://doi.org/10.1111/j.1468-5957.2011.02268.x

Krishnan, J., \& Schauer, P. C. (2000). The Differentiation of Quality among Auditors: Evidence from the Not-for-Profit Sector. Auditing: A Journal of Practice \& Theory, 19, 9-25. https://doi.org/10.2308/aud.2000.19.2.9 
Lawrence, A., Minutti-Meza, M., \& Zhang, P. (2011). Can Big 4 versus Non-Big 4 Differences in Audit-Quality Proxies Be Attributed to Client Characteristics? The Accounting Review, 86, 259-286. https://doi.org/10.2308/accr.00000009

Mansouri, A., Pirayesh, R., \& Salehi, M. (2009). Audit Competence and Audit Quality: Case in Emerging Economy. International Journal of Business and Management, 4, 17-25. https://doi.org/10.5539/ijbm.v4n2p17

Marsudi, A. S. (2020). Determinant of Quality Audit in Sustainable Development Goals. The 2nd International Conference on Inclusive Business in the Changing World, 1, 584-589. https://doi.org/10.5220/0008434005840589

Ningrum, G. S., \& Wedari, L. K. (2017). Impact of Auditor's Work Experience, Independence, Objectivity, Integrity, Competency and Accountability on Audit Quality. Journal Economics \& Business Atmajaya Indonesia, 1, 19-33.

O’Dwyer, B. (2011). The Case of Sustainability Assurance: Constructing a New Assurance Service. Contemporary Accounting Research, 28, 1230-1266. https://doi.org/10.1111/j.1911-3846.2011.01108.x

Octaviani, D., \& Ekasari, K. (2021). The Effect of Due Professional Care, Integrity, Confidentiality, and Independence on Audit Quality (An Insight of East-Java Auditors in Indonesian during Pandemic). Advances in Economics, Business and Management Research, Vol. 183, 106-110. https://doi.org/10.2991/aebmr.k.210717.022 https://file:///C:/Users/Dr.Sulaiman/Downloads/125959043.pdf

Oktari, K. A., Widnyana, I. W., \& Sapta, I. K. S. (2020). Effect of Competence and Independence on Quality of Audit Result Moderated by Auditor Ethics at the Regional Inspectorate of Klungkung. International Journal of Contemporary Research and Review, 11, 21846-21855.

Oraka, A., \& Okegbe, T. (2015). The Impact of Professional Accounting Ethics in Quality Assurance in Audit. International Journal of Academic Research in Business and Social Sciences, 5, 64-78. https://doi.org/10.6007/IJARBSS/v5-i8/1761

Pandoyo (2016). The Effect of Auditor Competence, Independence, Audit Experience, Organizational Culture and Leadership against Auditor Professionalism and Its Implication on Audit Quality. International Journal of Advanced Research, 4, 1632-1646. https://doi.org/10.21474/IJAR01/592

Pflugrath, G., Martinov-Bennie, N., \& Chen, L. (2007). The Impact of Codes of Ethics and Experience on Auditor Judgments. Managerial Auditing Journal, 220, 566-589. https://doi.org/10.1108/02686900710759389

Pinto, M., Rosidi, R., \& Baridwan, Z. (2020). Effect of Competence, Independence, Time Pressure and Professionalism on Audit Quality (Inspeção Geral Do Estado in Timor Leste). International Journal of Multicultural and Multireligious Understanding, 7, 658-667. https://doi.org/10.18415/ijmmu.v7i8.2013

Prabowo, D., \& Suhartini, D. (2021). The Effect of Independence and Integrity on Audit Quality: Is There a Moderating Role for e-Audit? Journal of Economics, Business, and Accountancy Ventura, 23, 305-319. https://doi.org/10.14414/jebav.v23i3.2348

Puspitasari, A., Baridwan, Z., \& Rahman, A. F. (2019). The Effect of Audit Competence, Independence, and Professional Skepticism on Audit Quality with Auditor's Ethics as Moderation Variables. International Journal of Business, Economics, and Law, 18, 135-144.

Ravenscroft, S., \& Williams, P. F. (2005). Rules, Rogues, and Risk Assessors: Academic Responses to Enron and Other Accounting Scandals. European Accounting Review, 14, 363-372. https://doi.org/10.1080/09638180500124889

Sanusi, Z. M., Isa, Y. M., Iskandar, T. M., \& Heang, L. T. (2014). Roles of Audit Oversight 
Bodies in Governing Financial Reporting. International Review of Management and Business Research, 3, 1220.

Satria, M. R. (2020). Effect of Auditor's Experience and Ethics on Audit Quality in Public Accountant Offices in Bandung City. Journal of Economic Empowerment Strategy, 3, 18-24. https://doi.org/10.30740/jees.v3i1.67

Schroeder, M. S., Solomon, I., \& Vickrey, D. (1986). Audit Quality: The Perceptions of Audit Committee Chairpersons and Audit Partners. Auditing: A Journal of Practice \& Theory, 5, 86-94.

Smith, M. (2019). Research Methods in Accounting (5th ed.). SAGE Publications Limited.

Sulaiman, N. A. (2018). Attributes and Drivers of Audit Quality: The Perceptions of Quality Inspectors in the UK. Asian Journal of Accounting and Governance, 10, 23-36. https://doi.org/10.17576/AJAG-2018-10-03

Sutton, S. G., \& Lampe, J. C. (1991). A Framework for Evaluating Process Quality for Audit Engagements. Accounting and Business Research, 21, 275-288. https://doi.org/10.1080/00014788.1991.9729841

Suyono, E. (2012). Determinant Factors Affecting the Audit Quality: An Indonesian Perspective. Global Review of Accounting and Finance, 3, 42-57.

Syamsuddin, I., Abdul, H., \& Mediaty, U. (2014). The Influences of Ethics, Independence, and Competence on the Quality of an Audit through the Influence of Professional Skepticism. Journal of Research in Business and Management, 2, 8-14.

Usman, A., Sudarma, M., Habbe, H., \& Said, D. (2014). Effect of Competence Factor, In-Dependence and Attitude against Professional Auditor Audit Quality Improve Performance in Inspectorate (Inspectorate Empirical Study in South Sulawesi Province). IOSR Journal of Business and Management, 16, 1-13.

https://doi.org/10.9790/487X-16120113

Van Raak, J., \& Thürheimer, U. (2016). Opportunities to Improve the Measurement of Audit Quality: A Call for Collaboration between the Profession and Academics. Maandblad voor Accountancy en Bedrijfseconomie, 90, 352-358. https://doi.org/10.5117/mab.90.31359

Wardayati, S. M. (2016). The Effects of Accountability, Objectivity, Integrity, Working Experience, Competence, Independence and Motivation of the Examiner toward the Quality of Inspection Results at the Inspectorate of Lumajang Regency. Pertanika Journals, 24, 165-174.

Watts, R. L., \& Zimmerman, J. L. (1986). Positive Accounting Theory.

Xiao, T., Geng, C., \& Yuan, C. (2020). How Audit Effort Affects Audit Quality: An Audit Process and Audit Output Perspective. China Journal of Accounting Research, 13, 109-127. https://doi.org/10.1016/j.cjar.2020.02.002

Zahmatkesh, S., \& Rezazadeh, J. (2017). The Effect of Auditor Features on Audit Quality. TÉKHNE-Review of Applied Management Studies, 9, 1-9. https://doi.org/10.1016/j.tekhne.2017.09.003

Zikmund, W. G., Babin, B. J., Carr, J. C., \& Griffin, M. (2010). Business Research Methods (8th ed.). South Western Cengage Learning. 